\title{
Academic Monitoring in Human Anatomy as a Pedagogical Tool in Higher Education
}

\section{A Monitoria Acadêmica em Anatomia Humana como Ferramenta Pedagógica no Ensino Superior}

\author{
Roger William de Souza Vitorino ${ }^{\mathrm{a}}$; Deisy Paula dos Santos ${ }^{\mathrm{a}}$; Luana Andrade Rogeria ${ }^{\mathrm{a}}$ Célia Cristina Fornaziero ${ }^{\mathrm{a}}$; \\ Mayara Bocchib; Eduardo Vignoto Fernandes*o
}

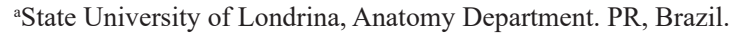

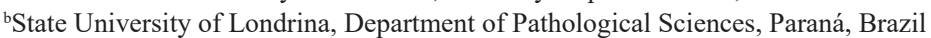 \\ 'Federal University of Goiás, Laboratory of Human and Comparative Anatomy. GO, Brazil. \\ *E-mails: eduardovignoto@uel.br; eduardovignoto@ufg.br \\ Recebido em: 31/07/2020 \\ Aprovado em: 02/12/2020
}

\begin{abstract}
The objective of the present study was to evaluate the contribution of academic monitoring in the students' performance of the Physical Education course in the discipline of Human Anatomy. The sample consisted of 50 students of the Physical Education course (Bachelor's degree) who were taking the discipline of Human Anatomy (HA). The participants were divided into two groups: non-monitoring (NM) and monitoring $(\mathrm{M})$. Academic monitoring actions were carried out during the students' after class hours, in which they were assisted by the professor and three monitors. Thus, all the students who participated in the monitoring activities were included in the M group and those students who were not involved in monitoring activities were included in the NM group. The assessment used to verify student's performance was the last test of the HA discipline. After verifying the data normality, the scores of the groups were compared using the Mann Whitney test. Data were expressed as mean and standard deviation from the mean using the Graph Pad Prism 6 statistical program. The adopted significance index was $\mathrm{p}<0.05$. In the results it was observed that the $\mathrm{M}$ group obtained a better performance when compared to the NM group $(\mathrm{p}<0.001)$. Therefore, academic monitoring acted as a facilitating tool in the student's theoretical-practical development and contributed to a better performance in the discipline of HA. Therefore, it can be used as an additional support in the teaching-learning process of students who participate in extra-class monitoring activities.
\end{abstract}

Keywords: Learning. Education, higher. Education.

\section{Resumo}

O objetivo do presente estudo foi avaliar a contribuição da monitoria acadêmica no desempenho dos estudantes do curso de Educação Física na disciplina de Anatomia Humana. A amostra foi composta por 50 estudantes do curso de Educação Física (Bacharelado) que cursavam a disciplina de Anatomia Humana (AH). Os participantes foram distribuidos em dois grupos: Sem Monitoria (SM) e Com Monitoria (CM). As ações de monitoria acadêmica foram realizadas no contraturno dos estudantes, no qual, foram auxiliados pelo docente e por três monitores. Dessa forma, todos os acadêmicos que participaram das atividades de monitoria foram inseridos no grupo CM e aqueles estudantes que não se envolveram com atividades de monitoria, foram incluidos no grupo SM. A avaliação utilizada para verificar o desempenho dos estudantes foi a última prova da disciplina de AH. Após verificar a normalidade dos dados, as notas dos grupos foram comparadas por meio do teste Mann Whitney. Os dados foram expressos em média e desvio padrão da média por meio do programa estatístico Graph Pad Prism 6.0 indice de significância adotado foi de $p<0,05$. Nos resultados foi observado que o grupo CM obteve um melhor rendimento quando comparado ao grupo $S M(p<0,001)$. Nesse sentido, a monitoria acadêmica atuou como ferramenta facilitadora no desenvolvimento teórico-prático do discente e contribuiu para um melhor rendimento na disciplina de AH. Sendo assim, pode ser utilizada como um suporte adicional no processo ensinoaprendizagem dos acadêmicos que participam das atividades de monitoria extraclasse.

Palavras-chave: Aprendizagem. Educação Superior. Educação.

\section{Introduction}

Human Anatomy (HA) is the science that studies the macroscopic morphology of human beings. Even though it is a classical science, it continues to present great relevance in courses in the biological and health areas, such as: Biology, Medicine, Nursing, Physiotherapy and Physical Education. In general, the discipline is still coursed in the first year of graduation, and the students soon realize that this knowledge is indispensable for the understanding of other disciplines throughout the course and also for their future professional performance ${ }^{1,2}$. According to Salbego et al. ${ }^{3}$, HA has still been learned in a merely from memory manner by the students and, such a condition, implies directly the level of learning being received, because it ends up becoming a superficial knowledge that can be quickly forgotten.

In this context, higher education has dealt with students who demonstrate difficulties in achieving their curricular goals. Therefore, many higher education institutions seek to innovate their pedagogical political projects in order to improve the teaching-learning process ${ }^{4}$. Over the years, a widely used strategy is the academic monitoring activities that reinforce the content taught by the professor ${ }^{5}$.

Academic monitoring is understood as a strategy to 
support teaching itself, in which the monitors (students who have already attended the discipline) assist in the students' learning in a specific discipline (e.g. HA), that is, work in conjunction with the professor (during class or after classes hour), acting diligently and actively in the teaching-learning process, providing an environment where students can clarify possible doubts, improve their knowledge and enhance their academic performance ${ }^{6,7}$. Studies show that the monitor plays a relevant role in this context, both in its own academic formation and in the learning process of those being assisted by the monitors ${ }^{8-10}$.

Officially, university monitoring was instituted on December $20^{\text {th }}, 1996$, by the Law of Guidelines and Base of National Education, Law no. 9.394, in which in its Article 84 it indicates that the graduates can be inserted into teaching and research activities by their respective institutions, developing monitoring functions, provided that it is in conformity with the pedagogical political project of the course ${ }^{11}$.

Once the student has experienced the discipline, he or she can, as a monitor, be a teacher-student intermediary, being able to perceive the students' difficulties. Thus, monitors and professors can discuss problems in order to improve the students' content understanding and propose new teaching strategies $^{12}$.

Thus, it can be observed that in the HA discipline, for the Physical Education course, the monitor can facilitate the theoretical and practical knowledge construction, and can transmit his or her experience and enable a more tangible and efficient learning path for the students, also serving as a bridge between the professor and the student ${ }^{8,10,13}$.

As a result, the objective of the present study was to evaluate the contribution of academic monitoring in the students' performance of the Physical Education course in the discipline of Human Anatomy.

\section{Material and Methods}

\subsection{Participants}

A total of 50 students of both sexes enrolled in the first year of physical Education (Bachelor's degree) in the night shift and who attended the HA discipline participated in the present study. The participants were divided into two groups: Non-Monitoring (NM, n=31) and Monitoring (M, n=19).

Subjects who did not perform the HA assessment, used to verify students' performance, were excluded from the study. The study was approved by the Ethics Committee in Human beings of State University of Londrina (CAAE: 79469417.4.0000.5231) and the participants signed the term of free and informed consent on the study conditions.

\subsection{Data Collection and study organization}

The academic monitoring program in HA took place in the first half of 2019 at the Department of Human Anatomy, State University of Londrina. The academic monitoring activities were carried out during the students' after classes period, during the monitoring, the students were assisted by the professor and three monitors (who also participated in the theoretical-practical classes), being performed only in a practical way through the use of cadaveric pieces.

At the beginning of the academic semester of 2019, the physical Education students enrolled in the HA discipline were informed that they could have the support of the extra class academic monitoring activities to address possible doubts and reinforce the content learned in the classroom. All the students who participated in the monitoring activities were included in the $\mathrm{M}$ group and those students who did not participate were included in the NM group. The evaluation used to verify the academic performance in the M and NM groups was the last semester evaluation.

\subsection{Statistical analysis}

Initially, the data were submitted to the Shapiro-Wilk normality test. After verifying the data normality, the scores of the groups were compared using the Mann Whitney test. Data were expressed as mean and standard deviation from the mean and the Graph Pad Prism 6 statistical program was used for the analyses. The adopted significance index was $\mathrm{p}<0.05$.

\section{Results and Discussion}

The HA discipline seeks to understand the morpho functional organization of the man's main organic systems. The contents discussed in this discipline are of great relevance in the students' professional practice ${ }^{3}$. Since the students have difficulties related to HA learning, the role of academic monitoring is highlighted, which is responsible for facilitating the teaching-learning process ${ }^{14}$.

Figure 1 shows the students' performance in relation to their respective groups, NM and $\mathrm{M}$. Thus, it was observed that the $\mathrm{M}$ group obtained a better performance when compared to the NM group $(\mathrm{p}<0.001)$.

Figure 1 - Comparison between the non-monitoring group and the monitoring group in relation to the students' performance

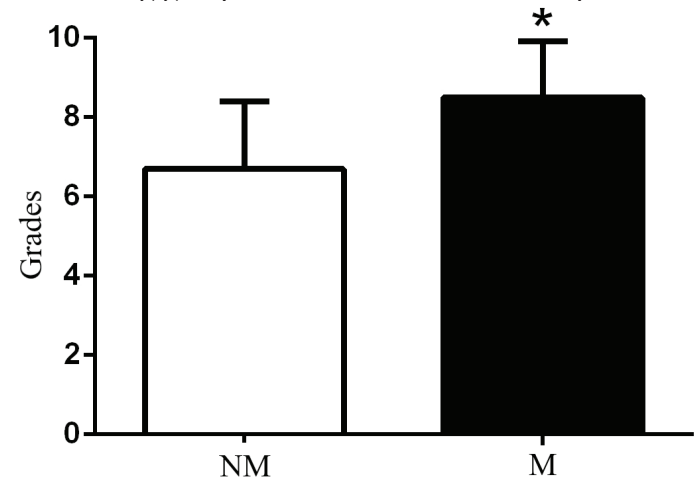

Mann-Whitney test was used to compare the groups, $\mathrm{p}<0.05$. NM, nonMonitoring ( $\mathrm{n}=31)$, monitoring $(\mathrm{n}=19) .{ }^{*}, \mathrm{M}$ different from NM.

Source: Research data.

The fact that the monitor has already experienced the 
status of a student in HA, envisages that he or she has the ability to notice the students' possible difficulties in relation to the contents of the discipline ${ }^{12}$. Such a condition may be a possible explanation for $\mathrm{M}$ group students to have better results in objective assessments in relation to NM group.

According to Batista and Souza Filho ${ }^{15}$, the monitoring provided for in the discipline of Anatomy has obtained several positive aspects in relation to academic processes, acting as an important pedagogical tool, which assists the professors and promotes improvements in the students' academic performance. Corroborating the above, Muniz et al. ${ }^{16}$, explained in their study that $99 \%$ of the students considered the monitoring action to be of paramount importance, recognizing that the presence of the monitor implies several benefits (since the same has already coursed the discipline which he or she monitors).

The relationship of monitoring and better academic performance, as well as in the present study, was also demonstrated in the study by Felicetti et al. ${ }^{17}$ in an Exact Sciences monitoring program at Centro Universitário La Salle, where the pass index was $74.2 \%$ and the fail index was only $25.8 \%$. Except for the discipline of physics (which did not count on the presence of monitors), the other disciplines involving mathematics obtained a positive result and the amount of monitoring visits requested by the students also reflected positively in the performance. According to these findings, Escobar and Kaminski ${ }^{18}$, in a study in the monitoring program in Bromatology and Food Biochemistry, at Federal University of Pampa, pointed out that during the semesters, when monitoring activities began to be offered, the number of passes increased.

Thus, the positive aspects of the academic monitoring presented demonstrate that it is a process of paramount importance and efficiency, because according to Andrade et al. ${ }^{19}$, it is recognized by professors and students as a facilitating tool for the achievement of an effective teachinglearning process, both for the one who exercises the monitor function, supervised by a leading professor, and for the monitored one, so that his or her knowledge and practices are consolidated. Furthermore, Bragagnolo ${ }^{5}$ points out that when monitoring is used to enhance the students' collaborative and self-regulated learning, it can be a stimulating factor for other aspects centered on the study, also bringing advances to students who benefit from monitoring, with good performance in the teaching-learning process.

\section{Conclusion}

It can be seen in the present study that academic monitoring was able to assist students in the Physical Education course as a tool that facilitates the student's theoretical-practical development, as well as contributed to a better performance in the HA discipline. Therefore, the academic monitoring was an additional support to the students' teaching-learning process, who attended the extra-class monitoring activities.

\section{References}

1. Cardinot T, Oliveira JD, Pedroso Júnior OV, Machado MA, Macedo MD, Aragão AD. Importância da disciplina de Anatomia Humana para os discentes de Educação Física e Fisioterapia da Abeu Centro Universitário de Belford Roxo/ RJ. Coleção Pesq Educ Fís 2014;13(1):95-102.

2. Ruzycki SM, Desy, JR, Lachman N, Wolanskyj-Spinner AP. Medical education for millennials: How anatomists are doing it right. Clin Anat 2019;32(1):20-25. doi: 10.1002/ca.23259

3. Salbego C, Oliveira EMDD, Silva MDARD, Bugança PR. Percepções acadêmicas sobre o ensino e a aprendizagem em anatomia humana. Rev Bras Educ Med 2015;39(1):23-31. doi: 10.1590/1981-52712015v39n1e00732014

4. Vicenzi CB, Conto F, Flores ME, Rovani G, Ferraz SCC. Marostega MGA. A monitoria e seu papel no desenvolvimento da formação acadêmica. Rev Ciênc Ext 2016;12(3): 88-94.

5. Frison LMB. Monitoria: uma modalidade de ensino que potencializa a aprendizagem colaborativa e autorregulada. Pro-Posições 2016;27(1):133-53. doi: 10.1590/01037307201607908

6. Botelho LV, Lourenço A EP, Lacerda MG. Wollz LEB. Monitoria acadêmica e formação profissional em saúde: uma revisão integrativa. ABCS Health Sci 2019;44(1):67-74. doi: 10.7322/abcshs.v44i1.1140

7. Silva DHM, Dos Santos Reis ER, Campos TA. Percepção dos discentes sobre a monitoria de anatomia sistêmica nos cursos de graduação em saúde: relato de experiência. Rev Eletr Estácio Recife 2019;5(1):1-10.

8. Burgos C, De Almeida Baricati CC, Martins JT, Scholze AR, Galdino MJQ, Karino M E. Monitoria acadêmica na percepção dos estudantes de enfermagem. Rev Enferm UFSM 2019;9(e37):1-14. doi: 10.5902/2179769230816

9. Caetano MK, De Oliveira FC, Paiva-Oliveira EL Contribuições da monitoria em Anatomia Humana para acadêmicos de Fisioterapia. Rev Cient Univiçosa 2017;8(1):272-278

10. Félix DF, Da Cunha CMQ, Troiani Neto G, Dos Santos Félix LC, Queiroz EF, Colares Junior R. Monitoria em anatomia: a percepção dos acadêmicos de medicina. Arch Health Scie 2018;25(3):53-5. doi: 10.17696/2318-3691.25.3.2018.1132

11. Silveira E, De Sales F. A importância do Programa de Monitoria no ensino de Biblioteconomia da Universidade do Estado de Santa Catarina (UDESC). Rev Cient Inf Doc 2016;7(1):13149. doi: 10.11606/issn.2178-2075.v7ilp131-149

12. Natário EG, Santos AAA. Programa de monitores para o ensino superior. Estud Psicol (Campinas) 2010;27(3):355-64. doi: 10.1590/S0103-166X2010000300007

13. Tavares JS, Oliveira FRD, Maia CMAFG, Rodrigues WFG. Contribuições da monitoria de Anatomia Humana na formação acadêmica de estudantes de enfermagem: relato de experiência. Rev Enferm UFPE 2017;11(8):3176-379. doi: 10.5205/1981-8963-v11i8a110225p3176-3179-2017

14. Souza JC, Souza MNA, De Lima NR, De Lima NR, De Lima AJG, Souza Filho JOA. Importância da anatomia humana e da monitoria acadêmica para estudantes de enfermagem. Anais da EXPO 2018;2018(1):8-8.

15. Batista MLB, Souza Filho JOA. Avaliação da monitoria da disciplina de Anatomia Humana da Faculdade Ateneu. Rev Saúde Ciênc 2017;6:310-440.

16. Muniz CES, Almeida AZF, Cardoso MKB, Paiva CA, Lima 
VE, Laranjeira E. Questionando a monitoria: intenções e práticas no ensino superior. Anais CINTEDI: Práticas Pedagógicas, Direitos Humanos e Interculturalidades. Campina Grande: Realize, 2014; 1.

17. Felicetti VL, Gomes KA, Fossatti P. Acadêmicos que frequentam a monitoria: comprometimento e aprovação. III CLABES 2013;1:1-10.
18. Escobar T, Kaminski TA. Monitoria e desempenho nos componentes curriculares de bromatologia e bioquímica dos alimentos. Anais SIEPE 2017;9(1):1-5.

19. Andrade EGR, Rodrigues ILA, Nogueira LMV, Souza DF. Contribution of academic tutoring for the teaching-learning process in Nursing undergraduate studies. Rev Bras Enferm 2018. doi: 10.1590/0034-7167-2017-0736 